\title{
PENERAPAN AKUNTANSI PENGAKUAN ASET TETAP PADA BADAN PENGELOLA KEUANGAN DAN ASET DAERAH KABUPATEN MINAHASA
}

\author{
Aprico Aring ${ }^{1}$, Jantje J. Tinangon ${ }^{2}$, Inggriani Elim ${ }^{3}$ \\ 1,2,3Jurusan Akuntansi, Fakultas Ekonomi dan Bisnis, Universitas Sam Ratulangi, Jl. Kampus Bahu, Manado, \\ 95115, Indonesia \\ E-mail: josuarico4@gmail.com
}

\begin{abstract}
Assets can still be used for mutual interests between the government and the general public and can be directly felt for their usefulness. Recognition of fixed assets is regulated in Republic Indonesian Government Regulation No. 71 of 2010 concerning Public Accounting Standards Statement which includes the accrual basis as applicable SAP. This study aims to determine the extent on application of accounting for the recognition of fixed assets. The method of analysis used in this study is a descriptive method in which the purpose of each data collected is analyzed and drawn a conclusion and the type of research conducted is descriptive qualitative. The results of the study found that the process of recognizing fixed assets at the Minahasa District Financial and Asset Management Agency is in accordance with applicable regulations.
\end{abstract}

Keywords: implementation; recognition; fixed asset; government; accounting

\section{PENDAHULUAN}

Pemerintah daerah diharapkan dapat mengelola sumber daya yang dimilikinya dan melaksanakan tata kelola pemerintahan yang baik sehingga akan berdampak pada pelayanan publik yang meliputi akuntabilitas dan transparansi demi tercapainya good governance. Pemerintah daerah dalam hal ini yang melakukan pengelolaan terhadap segala sumber daya daerah harus memperhatikan setiap detail yang ada dalam pelaporan keuangan sebagai bentuk akuntabilitas terhadap publik. Pengelolaan keuangan daerah pastinya akan menghasilkan laporan keuangan yang akan menunjang terselenggaranya good governance. Setiap laporan keuangan yang ada tentunya harus memperhatikan segala aspek yang diatur dalam undang-undang tentang pengelolaan keuangan daerah.

Dalam mewujudkan transparansi keuangan ini salah satu hal yang perlu diperhatikan adalah bagaimana pemerintah mengelola aset yang dimilikinya. Aset suatu daerah sangat berperan penting dalam pembangunan suatu daerah. Ada bermacam-macam aset yang dimiliki pemerintah. Salah satunya adalah aset tetap yang manfaatnya dapat langsung dirasakan penggunaannya dan dapat dipakai organisasi perangkat daerah untuk lebih maksimal dalam kerja mereka, untuk itu dalam pengakuan aset tetap menjadi aset milik daerah harus juga diperhatikan.

Dalam mengakui suatu aset tetap menjadi barang milik negara atau daerah tentunya membutuhkan sistem. Dalam hal ini pengakuan aset tetap yang terjadi dalam setiap lingkup pemerintah menggunakan satu instrumen yaitu peraturan yang disusun pemerintah. Pengakuan aset tetap sendiri mempunyai beberapa aspek yang harus dipenuhi. Hal ini membutuhkan bukan hanya peraturan yang ada akan tetapi membutuhkan juga sumber daya manusia yang berkompeten untuk melaksanakannya. Dari beberapa aspek diatas maka perlu dilihat bagaimana penerapan akuntansi aset tetap ini pada entitas akuntansi pemerintah. 


\section{TINJAUAN PUSTAKA}

Akuntansi. Suwardjono (2015:10) menyatakan bahwa akuntansi dapat didefinisikan sebagai ilmu yang mempelajari perekayasaan penyediaan jasa berupa informasi keuangan kuantitatif unit-unit organisasi dalam suatu lingkungan negara tertentu dan cara penyampaian (pelaporan) informasi tersebut kepada pihak yang berkepentingan untuk dijadikan dasar dalam pengambilan keputusan ekonomi. Dalam arti sempit, akuntansi merupakan proses, fungsi, atau praktik, akuntansi dapat didefinisikan sebagai proses pengidentifikasian, pengesahan, pengukuran, pengakuan, pengklasifikasian, penggabungan, peringkasan, dan penyajian data keuangan dasar (bahan olah akuntansi) yang terjadi dari kejadian-kejadian, transaksi-transaksi, atau kegiatan operasi suatu unit organisasi dengan cara tertentu untuk menghasilkan informasi yang relevan bagi pihak yang berkepentingan.

Akuntansi sektor publik. Sektor publik merupakan sebuah entitas ekonomi yang memiliki keunikan tersendiri. Pada organisasi sektor publik juga melakukan transaksitransaksi ekonomi dan keuangan namun berbeda dengan entitas ekonomi yang lain, khususnya perusahaan komersial yang mencari laba, dimana sumber daya ekonomi organisasi sektor publik di kelola tidak untuk tujuan mencari laba (nirlaba). Akuntansi sektor publik dapat diartikan sebagai aktivitas jasa yang terdiri dari mencatat, mengklasifikasikan, dan melaporkan kejadian atau transaksi ekonomi yang akhirnya menghasilkan suatu informasi keuangan yang akan dibutuhkan pihak-pihak tertentu untuk pengambilan keputusan, yang diterapkan pada pengelolaan dana publik di lembaga-lembaga tinggi negara dan departemendepartemen dibawahnya (Sujarweni 2015:1). Siregar (2015:3) mengungkapkan akuntansi sektor publik merupakan aktivitas akuntansi yang dilakukan terhadap kejadian dan transaksi keuangan organisasi sektor publik. Akuntansi sektor publik dapat dinyatakan sebagai aktifitas akuntansi yang diterapkan pada pemerintahan, baik pemerintah pusat maupun pemerintah daerah. Mardiasmo (2009:2) menyatakan akuntansi sektor publik adalah alat informasi, baik bagi pemerintah sebagai manajemen maupun alat informasi bagi publik. Akuntansi sektor publik berkaitan dengan tiga hal pokok yaitu penyedia informasi, pengendalian manajemen dan akuntabilitas. Organisasi sektor publik adalah sebuah entitas ekonomi yang menyediakan barang dan atau jasa publik untuk meningkatkan kesejahteraan masyarakat dan bukan untuk mencari keuntungan finansial. Organisasi sektor publik disebut sebagai entitas ekonomi karena organisasi ini memiliki dan mengelolah sumber daya ekonomi yang tidak kecil serta melakukan transaksi-transaksi ekonomi dan keuangan. Menurut Nordiawan dan Hertianti (2010:4), organisasi sektor publik menjadi berbeda dengan ciri-ciri berikut: (a) dijalankan untuk tidak mencari keuntungan finansial, melainkan untuk mencapai suatu misi atau tujuan tertentu; (b) dimiliki secara kolektif oleh publik; (c) kepemilikan atas sumber daya tidak digambarkan dalam bentuk saham yang dapat diperjual belikan; dan (d) keputusan-keputusan yang terkait kebijakan maupun operasi sering kali di dasarkan pada konsensus.

Pengelolaan keuangan daerah. Pengertian dan ruang lingkup pengelolaan keuangan daerah menurut Peraturan Menteri Dalam Negeri Republik Indonesia Nomor 21 Tahun 2011 keuangan daerah adalah semua hak dan kewajiban daerah dalam rangka penyelenggaraan pemerintahan daerah yang dapat dinilai dengan uang termasuk didalamnya segala bentuk kekayaan yang berhubungan dengan hak dan kewajiban daerah tersebut. Pengelolaan keuangan daerah adalah keseluruhan kegiatan yang meliputi perencanaan, pelaksanaan, penatausahaan, pelaporan, pertanggungjawaban, dan pengawasan keuangan daerah. Dasar hukum dalam pelaporan keuangan daerah adalah Peraturan Pemerintah Republik Indonesia Nomor 71 Tahun 2010 tentang Standar Akuntansi Pemerintahan dan Peraturan Menteri Dalam Negeri Republik Indonesia Nomor 64 Tahun 2013 tentang Penerapan Akuntansi Pemerintahan Berbasis Akrual Pada Pemerintah Daerah.

Laporan keuangan daerah adalah hasil dari proses akuntansi keuangan daerah yang berisi Neraca, Laporan Realisasi Anggaran (LRA), Laporan Perubahan Saldo Anggaran 
Lebih (LP-SAL), Laporan Oprasional (LO), Laporan Perubahan Ekuitas (LPE), Laporan Arus Kas (LAK) dan Catatan atas Laporan Keuangan (CaLK), untuk digunakan oleh pihakpihak yang berkepentingan, baik pihak internal maupun eksternal (Masun et al., 2011:92). Laporan keuangan daerah disusun untuk menyediakan informasi yang relevan mengenai posisi keuangan dan seluruh transaksi yang dilakukan pemerintah daerah selama satu periode pelaporan. Laporan keuangan pemerintah daerah terutama digunakan untuk membandingkan realisasi pendapatan dan belanja dengan anggaran yang telah ditetapkan menilai kondisi keuangan, menilai efektivitas dan efisiensi serta membantu ketaatannya terhadap peraturan perundang-undangan. Pemerintah daerah wajib melaporkan upaya-upaya yang telah dilakukan serta hasil yang dicapai dalam pelaksanaan kegiatan secara sistematis dan terstruktur pada suatu periode pelaporan untuk kepentingan.

a. Akuntabilitas. Mempertanggungjawabkan pengelolaan sumber daya dan pelaksanaan kebijakan yang dipercayakan pada pemerintah daerah dalam mencapai tujuan yang telah ditetapkan secara periodik.

b. Manajemen. Membantu para pengguna laporan keuangan untuk mengevaluasi pelaksanaan kegiatan pemerintah daerah dalam periode pelaporan sehingga memudahkan fungsi perencanaan, pengelolaan dan pengendalian atas seluruh aset, kewajiban dan ekuitas dana pemerintah daerah untuk kepentingan masyarakat.

c. Transparansi. Memberikan informasi keuangan yang terbuka dan jujur kepada masyarakat berdasarkan pertimbangan bahwa masyarakat berhak mengetahui secara terbuka dan menyeluruh atas pertanggungjawaban pemerintah daerah dalam pengelolaan sumber daya yang dipercayakan kepadanya dan ketaatannya pada perundang-undangan.

d. Keseimbangan antar Generasi (Intergenerational equity). Membantu pengguna laporan untuk mengetahui apakah penerimaan pemerintah daerah pada periode pelaporan cukup untuk membiayai seluruh pengeluaran yang dialokasikan dan apakah generasi mendatang diasumsikan ikut menanggung beban pengeluaran tersebut.

e. Evaluasi kinerja. Mengevaluasi kinerja entitas pelaporan, terutama dalam penggunaan sumber daya ekonomi yang dikelola pemerintah untuk mencapai kinerja yang direncanakan.

Tujuan laporan keuangan daerah, menyajikan informasi yang bermanfaat bagi para pengguna laporan dalam menilai akuntabilitas dan manfaat keputusan baik keputusan ekonomi, sosial, maupun politik dengan:

a. Menyediakan informasi apakah penerimaan periode berjalan cukup untuk membiayai seluruh pengeluaran.

b. Menyediakan informasi menegenai apakah cara memperoleh sumber daya ekonomi dan alokasinya telah sesuai dengan anggaran yang ditetapkan dan peraturan perundangundangan.

c. Menyediakan informasi mengenai jumlah sumber daya ekonomi yang digunakan dalam kegiatan pemerintah daerah dan hasil-hasil yang dicapai.

d. Menyediakan informasi mengenai bagaimana pemerintah daerah mendanai seluruh kegiatan dan mencukupi kebutuhan kasnya.

e. Menyediakan informasi mengenai posisi keuangan dan kondisi pemerintah daerah berkaitan dengan sumber-sumber penerimaannya, baik jangka panjang maupun jangka pendek termasuk yang berasal dari penerimaan pajak dan pinjaman.

f. Menyediakan informasi mengenai perubahan posisi keuangan pemerintah daerah apakah mengalami kenaikan atau penurunan sebagai akibat kegiatan yang dilakukan selama periode pelaporan.

Untuk memenuhi tujuan-tujuan tersebut, laporan keuangan pemerintah daerah menyediakan informasi mengenai pendapatan, belanja, pembiayaan, aset, kewajiban, ekuitas dana dan arus kas pemerintah daerah (Hariadi et al., 2010:122-123). Sistem akuntansi 
pemerintah daerah, menurut Peraturan Menteri Dalam Negeri Republik Indonesia Nomor 64 Tahun 2013 tentang Penerapan Akuntansi Pemerintahan Berbasis Akrual pada Pemerintah Daerah, sistem akuntansi pemerintah daerah adalah rangkaian sistematik dari prosedur, penyelenggara, peralatan dan elemen lain untuk mewujudkan fungsi akuntansi sejak analisis transaksi sampai dengan pelaporan keuangan di lingkungan organisasi pemerintahan daerah. Sistem akuntansi pemerintah daerah memuat pilihan prosedur dan teknik akuntansi dalam melakukan identifikasi transaksi, pencatatan pada jurnal, posting ke dalam buku besar, penyusunan neraca saldo serta penyajian laporan keuangan. Penyajian laporan keuangan yang dimaksud terdiri atas: (a) Laporan Realisasi Anggaran; (b) Laporan Perubahan Saldo Anggaran Lebih; (c) Neraca; (d) Laporan Operasional; (e) Laporan Arus Kas; (f) Laporan Perubahan Ekuitas; dan (g) Catatan atas Laporan Keuangan. Sistem akuntansi pemerintah daerah terdiri atas:

a. Sistem akuntansi Pejabat Pengelola Keuangan Daerah (PPKD). Sistem akuntansi Pejabat Pengelola Keuangan Daerah (PPKD) mencakup teknik pencatatan, pengakuan dan pengungkapan atas pendapatan pada Laporan Operasional, beban, pendapatan pada Laporan Realisasi Anggaran, belanja, transfer, pembiayaan, aset, kewajiban, ekuitas, penyesuaian dan koreksi, penyusunan laporan keuangan PPKD serta penyusunan laporan keuangan konsolidasian pemerintah daerah.

b. Sistem akuntansi Satuan Kerja Perangkat Daerah (SKPD). Sistem akuntansi Satuan Kerja Perangkat Daerah (SKPD) mencakup teknik pencatatan, pengakuan dan pengungkapan atas pendapatan pada Laporan Operasional, beban, pendapatan pada Laporan Realisasi Anggaran, belanja, aset, kewajiban, ekuitas, penyesuian dan koreksi, penyusunan laporan keuangan SPKD.

Pengakuan aset tetap. Aset tetap adalah aset yang memiliki wujud fisik dan memberikan manfaat ekonomi kepada entitas bisnis selama lebih dari satu periode akuntansi pada masa-masa yang akan dating (Purba, 2013:2). Pernyataan Standar Akuntansi Pemerintahan (PSAP) Nomor 7 menyatakan bahwa aset tetap adalah aset berwujud yang mempunyai masa manfaat lebih dari 12 bulan untuk digunakan atau dimaksudkan untuk digunakan dalam kegiatan pemerintah atau dimanfaatkan oleh masyarakat umum. Aset tetap diklasifikasikan berdasarkan kesamaan dalam sifat atau fungsinya dalam aktivitas operasi entitas. Klasifikasi aset tetap menurut PSAP Nomor 7 adalah tanah, peralatan dan mesin, gedung dan bangunan, jalan, irigasi, dan jaringan, aset tetap lainnya, dan konstruksi dalam pengerjaan. Pengakuan aset tetap menurut PSAP Nomor 07 aset tetap diakui pada saat manfaat ekonomi masa depan dapat diperoleh dan nilainya dapat diukur dengan handal. Untuk dapat diakui sebagai aset tetap harus dipenuhi kriteria sebagai berikut: (a) berwujud; (b) mempunyai masa manfaat lebih dari 12 (dua belas) bulan; (c) biaya perolehan aset dapat diukur secara andal; (d) tidak dimaksudkan untuk dijual dalam operasi normal entitas; dan (e) diperoleh atau dibangun dengan maksud untuk digunakan.

Dalam menentukan apakah suatu aset tetap mempunyai manfaat lebih dari 12 (dua belas) bulan, suatu entitas harus menilai manfaat ekonomi masa depan yang dapat diberikan oleh aset tetap tersebut, baik langsung maupun tidak langsung, bagi kegiatan operasional pemerintah. Manfaat tersebut dapat berupa aliran pendapatan atau penghematan belanja bagi pemerintah. Manfaat ekonomi masa depan akan mengalir ke suatu entitas dapat dipastikan bila entitas tersebut akan menerima manfaat dan menerima risiko terkait. Kepastian ini biasanya hanya tersedia jika manfaat dan risiko telah diterima entitas tersebut, dan sebelum hal ini terjadi, perolehan aset tidak dapat diakui.

Tujuan utama dari perolehan aset tetap adalah untuk digunakan oleh pemerintah dalam mendukung kegiatan operasionalnya dan bukan dimaksudkan untuk dijual. Pengakuan aset tetap akan andal bila aset tetap telah diterima atau diserahkan hak kepemilikannya dan atau pada saat penguasaannya berpindah. Saat pengakuan aset akan dapat diandalkan apabila 
terdapat bukti bahwa telah terjadi perpindahan hak kepemilikan dan/atau penguasaan secara hukum, misalnya sertifikat tanah dan bukti kepemilikan kendaraan bermotor. Apabila perolehan aset tetap belum didukung dengan bukti secara hukum dikarenakan masih adanya suatu proses administrasi yang diharuskan, seperti pembelian tanah yang masih harus diselesaikan proses jual beli (akta) dan sertifikat kepemilikannya di instansi berwenang, maka aset tetap tersebut harus diakui pada saat terdapat bukti bahwa penguasaan atas aset tetap tersebut telah berpindah, misalnya telah terjadi pembayaran dan penguasaan atas sertifikat tanah atas nama pemilik sebelumnya. Pihak-pihak yang terkait dalam sistem akuntansi aset tetap antara lain adalah:

a. Bendahara Barang atau Pengurus Barang. Dalam sistem akuntansi aset tetap, bendahara barang/pengurus barang bertugas untuk menyiapkan dan menyampaikan dokumendokumen atas pengelolaan aset tetap.

b. Bendahara Pengeluaran. Dalam sistem akuntansi aset tetap, bendahara pengeluaran bertugas untuk menyiapkan dan menyampaikan dokumen-dokumen atas transaksi tunai yang berkaitan dengan aset tetap.

c. Pejabat Pelaksana Teknis Kegiatan. Dalam sistem akuntansi aset tetap, pejabat pelaksana teknis kegiatan bertugas untuk menyiapkan dokumen atas beban pengeluaran pelaksanaan pengadaan aset tetap.

d. Pejabat Penatausahaan Keuangan. Dalam sistem akuntansi aset tetap, pejabat penatausahaan keuangan SKPD bertugas untuk melakukan proses akuntansi aset tetap yang dimulai dari jurnal hingga penyajian laporan keuangan SKPD.

Dokumen-dokumen yang digunakan dalam sistem akuntansi aset tetap antara lain:

a. Bukti Belanja/Pembayaran Aktiva Tetap. Dokumen ini merupakan dokumen sumber untuk melakukan jurnal pengakuan aktiva tetap dan belanja modal dengan cara pembayaran Uang Persediaan (UP).

b. Berita Acara Serah Terima Barang/Pekerjaan. Dokumen ini merupakan dokumen sumber untuk melakukan jurnal atas pengakuan aktiva tetap dengan cara pembayaran LS.

c. Surat Perintah Pencairan Dana Langsung ( SP2D LS). Dokumen ini merupakan dokumen sumber untuk pengakuan belanja modal dengan cara pembayaran LS.

d. Surat Permohonan Kepala SKPD tentang Penghapusan Aset Tetap. Dokumen ini merupakan dokumen sumber pengakuan reklasifikasi aset tetap menjadi aset lainnya.

e. Surat Keputusan Kepala Daerah tentang Penghapusan Aset. Dokumen ini merupakan dokumen sumber untuk pengakuan penghapusan aset tetap.

f. Berita Acara Pemeriksaan Kemajuan Pekerjaan. Dokumen ini merupakan dokumen sumber untuk pengakuan aset tetap konstruksi dalam pekerjaan.

Penelitian terdahulu. Kolinug et al. (2015) menunjukkan bahwa DPPKAD Kota Tomohon sebagai pembantu pengelola telah menerapkan 6 siklus dalam pengelolaan aset tetap. Dari 15 dokumen sumber yang diperlukan hanya ada 13 dokumen saja, sehingga pengelolaan aset tetap pada DPPKAD Kota Tomohon dengan Permendagri Nomor 17 Tahun 2007 belum sepernuhnya sesuai. Tipan et al. (2016) menunjukkan bahwa penyusutan terhadap aset tetap Dinas PU belum sesuai dengan PSAP yang berlaku. Engka et al. (2017) menemukan bahwa Pernyataan Stadar Akuntansi Pemerintahan (PSAP) No. 07 tentang Akuntansi Aset Tetap pada Kantor Badan Diklat Pemerintah Sulawesi Utara dalam penerapannya telah sesuai dengan PSAP No. 07.

\section{METODE PENELITIAN}

Sumber data dibedakan menjadi 2 (dua) jenis yaitu sumber data primer dalam penelitian ini adalah wawancara langsung yang dilakukan di Badan Pengelola Keuangan dan Aset Daerah, sedangkan sumber data sekunder adalah penelitian yang bersumber dari buku, jurnal serta bahan informasi lainnya. Jenis data yang dipakai adalah jenis data kualitatif yang 
diperoleh lewat wawancara dan observasi. Jenis penelitian yang digunakan dalam penelitian ini adalah jenis penelitian yang bersifat deskriptif. Menurut Sugiyono (2011:147), analisis deskriptif adalah cara mendeskripsikan atau menggambarkan data yang telah terkumpul. Lokasi penelitian bertempat di Badan Pengelola Keuangan dan Aset Daerah Kabupaten Minahasa.

\section{HASIL PENELITIAN DAN PEMBAHASAN}

\subsection{Hasil penelitian}

Badan Pengelola Keuangan dan Aset Daerah Kabupaaten Minahasa adalah Organisasi Perangkat Daerah (OPD) yang dibentuk untuk menjalankan tugasnya sebagaimana mestinya. Badan Pengelola Keuangan dan Aset Daerah merupakan unsur penunjang urusan pemerintahan di bidang keuangan yang menjadi kewenangan daerah. Badan Pengelola Keuangan dan Aset Daerah sebagaimana dimaksud dipimpin oleh Kepala Badan yang berkedudukan di bawah dan bertanggung jawab kepada Bupati. Badan Pengelola Keuangan dan Aset Daerah sebagaimana dimaksud mempunyai tugas membantu Bupati melaksanakan fungsi penunjang urusan pemerintahan di bidang keuangan yang menjadi kewenangan daerah dan tugas pembantuan yang diberikan kepada Badan Pengelola Keuangan dan Aset Daerah dalam melaksanakan tugas sebagaimana dimaksud menyelenggarakan fungsi: (a) penyusunan kebijakan teknis di bidang pengelolaan keuangan dan aset daerah; (b) pelaksanaan tugas dukungan teknis di bidang pengelolaan keuangan dan aset daerah; (c) pemantauan, evaluasi, dan pelaporan pelaksanaan tugas dukungan teknis di bidang pengelolaan keuangan dan aset daerah; (d) pembinaan teknis penyelenggaraan fungsi-fungsi penunjang urusan pemerintahan daerah di bidang pengelolaan keuangan dan aset daerah; (e) pelaksanaan administrasi Badan Pengelola Keuangan dan Aset Daerah; dan (f) pelaksanaan fungsi lain yang diberikan oleh Bupati terkait dengan tugas dan fungsinya.

Berdasarkan hasil wawancara pada Badan Pengelola Keuangan dan Aset Daerah (selanjutnya di singkat BPKAD) Kabupaten Minahasa ditemukan bahwa BPKAD Kabupaten Minahasa telah menerapkan Peraturan Pemerintah Nomor 71 tahun 2010 tentang Pernyataan Standar Akuntansi Pemerintah dan segala yang menyangkut laporan keuangan daerah melalui Sistem Informasi Manajemen Daerah (SIMDA). Salah satu produk akuntansi dari Pemerintah Kabupaten Minahasa yaitu Peraturan Bupati Minahasa Nomor 70 Tahun 2015 tentang Kebijakan Akuntansi Pemerintah Kabupaten Minahasa. Menurut Bapak Welly Pantouw sebagai Kepala Bidang Barang Milik Daerah bahwa, "semua yang menyangkut mengenai pencatatan dan pelaporan keuangan daerah terlebih khusus mengenai aset tetap mengacu pada peraturan tersebut".

Peraturan tentang kebijakan akuntansi di Kabupaten Minahasa terdapat dalam Peraturan Bupati Minahasa Nomor 70 Tahun 2015 Tentang Kebijakan Akuntansi Pemerintah Daerah Kabupaten Minahasa. Peraturan pemerintah ini telah mengatur sepenuhnya kebijakan akuntansi termasuk didalamnya tentang pengakuan aset. Pengakuan terhadap aset yang terkandung dalam Peraturan Bupati Minahasa Nomor 70 Tahun 2015 Tentang Kebijakan Akuntansi Pemerintah Kabupaten Minahasa adalah kebijakan akuntansi aset tetap dan pengakuan aset tetap. Pada umumnya aset tetap diakui pada saat manfaat ekonomi masa depan dapat diperoleh dan nilainya dapat diukur. Untuk dapat diakui sebagai aset tetap harus dipenuhi seluruh kriteria sebagai berikut: (a) berwujud; (b) mempunyai masa manfaat lebih dari 12 (dua belas) bulan; (c) biaya perolehan aset dapat diukur secara andal; (d) tidak dimaksudkan untuk dijual dalam operasi normal entitas; dan atau diserahkan kepada masyarakat atau pihak ketiga; (e) diperoleh atau dibangun dengan maksud untuk digunakan; (f) aset tersebut membutuhkan belanja pemeliharaan; dan (g) nilai Rupiah pembelian barang tersebut memenuhi batasan minimal kapitalisasi aset tetap yang telah ditetapkan. 
Namun demikian, pertimbangan biaya dan manfaat serta kepraktisan, pengakuan aset tetap berupa konstruksi dilakukan pada saat realisasi belanja modal. Dalam menentukan apakah suatu aset tetap mempunyai manfaat lebih dari 12 (dua belas) bulan, suatu entitas harus menilai manfaat ekonomi masa depan yang dapat diberikan oleh aset tetap tersebut, baik langsung maupun tidak langsung, bagi kegiatan operasional pemerintah. Manfaat tersebut dapat berupa aliran pendapatan atau penghematan belanja bagi pemerintah. Manfaat ekonomi masa depan akan mengalir ke suatu entitas dapat dipastikan bila entitas tersebut akan menerima risiko terkait. Kepastian ini biasanya hanya tersedia jika manfaat dan risiko telah diterima entitaas tersebut. Sebelum hal ini terjadi, perolehan aset tidak dapat diakui. Tujuan utama dari perolehan aset tetap adalah untuk digunakan oleh pemerintah.

\subsection{Pembahasan}

Hasil penelitian yang dilakukan bahwa Badan Pengelola Keuangan dan Aset Daerah Kabupaten Minahasa telah melakukan pengakuan aset tetap sesuai dengan Standar Akuntansi Pemerintahan yang berlaku yaitu Peraturan Pemerintah Nomor 71 Tahun 2010 tentang Standar Akuntansi Pemerintah dan kemudian mengeluarkan produk akuntansi milik daerah berupa Peraturan Bupati Minahasa 70 Tahun 2015 tentang Kebijakan Akuntansi Pemerintah Daerah. Badan Pengelola Keuangan dan Aset Daerah telah melakukan dengan baik pengakuan aset tetap di lingkungannya. Seluruh prosedur telah dilakukan melalui Sistem Informasi Manajemen Daerah (SIMDA), dimana pengakuan aset tetap sendiri terjadi ketika barang sudah ada dan langsung di masukan dalam SIMDA sehingga memudahkan para staf melakukan pekerjaan mereka.

\section{KESIMPULAN DAN SARAN \\ 5.1. Kesimpulan}

Berdasarkan uraian dan pembahasan mengenai pengakuan aset tetap pada Badan Pengelola Keuangan dan Aset Daerah Kabupaten Minahasa dapat mengambil kesimpulan sebagai berikut:

a. Akuntansi pengakuan aset tetap yang dilakukan Badan Pengelola Keuangan dan Aset Daerah Kabupaten Minahasa dilaksanakan sesuai dengan Peraturan Pemerintah Nomor 71 Tahun 2011 tentang Standar Akuntansi Pemerintah.

b. Akuntansi pengakuan aset tetap Badan Pengelola Keuangan dan Aset Daerah Kabupaten Minahasa didukung dengan Peraturan Bupati Nomor 70 Tahun 2015 tentang kebijakan akuntansi pemerintah Kabupaten Minahasa.

\subsection{Saran}

Saran atas penelitian ini adalah untuk meningkatkan pengelolaan akuntansi pengakuan aset tetap pada Badan Pengelola Keuangan dan Aset Daerah Kabupaten Minahasa.

\section{DAFTAR PUSTAKA}

Engka, F. K., Tinangon, J. J., \& Wokas, H. R. N. (2017). Analisis penerapan PSAP No. 07 tentang akuntansi aset tetap pada Badan Diklat Pemerintah Provinsi Sulawesi Utara. Going Concern : Jurnal Riset Akuntansi, 12(2), 18-24. https://doi.org/10.32400/gc.12.2.17385.2017

Hariadi, P., Restianto, Y. E., \& Bawono, I. R. (2010). Pengelolaan keuangan daerah, Edisi 1. Jakarta: Salemba Empat.

Kolinug, M., Ilat, V., \& Pinatik, S. (2015). Analisis pengelolaan aset tetap pada Dinas Pendapatan Pengelolaan Keuangan dan Aset Daerah Kota Tomohon. Jurnal EMBA: Jurnal Riset Ekonomi, Manajemen, Bisnis dan Akuntansi. 3(1), 818-830. http://ejournal.unsrat.ac.id/index.php/emba/article/view/7556 
Masun, M., Sulistyowati, F., \& Purwanugraha, A. H. (2011). Akuntansi sektor publik, Edisi 3. Yogyakarta: BPFE.

Mardiasmo. (2009). Akuntansi sektor publik. Yogyakarta: Penerbit Andi.

Nordiawan, D., \& Hertianti, A. (2010). Akuntansi sektor publik, Edisi 2. Jakarta: Salemba Empat.

Peraturan Bupati Minahasa Nomor 70 Tahun 2015 tentang Kebijakan Akuntansi Pemerintah Daerah Kabupaten Minahasa.

Peraturan Menteri Dalam Negeri Republik Indonesia Nomor 64 Tahun 2013 tentang Penerapan Standar Akuntansi Pemerintahan Berbasis Akrual Pada Pemerintah Daerah.

Peraturan Menteri Dalam Negeri Republik Indonesia Nomor 21 Tahun 2011 tentang Pedoman Pengelolaan Keuangan Daerah.

Peraturan Pemerintah Nomor 71 Tahun 2010 tentang Standar Akuntansi Pemerintahan.

Purba, M. P. (2013). Akuntansi keuangan aset tetap dan aset tak berwujud, Edisi 1. Yogyakarta: Graha Ilmu.

Tipan, A., Saerang. D. P. E., \& Lambey, R. (2016). Analisis perlakuan akuntansi aset tetap pada Dinas Pekerjaan Umum (PU) Provinsi Sulawesi Utara, 11(1), 57-65. https://doi.org/10.32400/gc.11.1.10558.2016.

Sugiyono. (2011). Metode penelitian kuantiatif, kualitatif dan R\&D. Bandung: Alfabeta.

Sujarweni, V. W. (2015). Akuntansi sektor publik. Yogyakarta: Pustaka Baru Press.

Suwardjono. (2015). Teori akuntansi perekayasaan laporan keuangan, Edisi 3. Yogyakarta: BPFE.

Siregar, B. (2015). Akuntansi sektor publik (akuntansi keuangan daerah berbasis akrual), Edisi Kedua. Yogyakarta: UPP STIM YKPN. 